\title{
ZMIANA MODELU SŁUŻBY CYWILNEJ PO NOWELIZACJI USTAWY O SEUŻBIE CYWILNEJ
}

I. Od 23 stycznia 2016 r. obowiązuje ustawa z 30 grudnia 2015 r. o zmianie ustawy o służbie cywilnej oraz niektórych innych ustaw ${ }^{1}$, która w istotny sposób zmienia zasady funkcjonowania służby cywilnej w Polsce. Nowelizacja weryfikuje dotychczasowy model kariery i wprowadza elementy ścisłego podporządkowania oraz zwiększa dowolność w procesie zatrudniania i rozwiązywania stosunku pracy wśród zatrudnionych w służbie cywilnej.

Główne zmiany w ustawie o służbie cywilnej ${ }^{2}$ dokonane ustawą z 30 grudnia 2015 r. polegają na weryfikacji zasady zatrudniania na wyższych stanowiskach w służbie cywilnej - rezygnacji z zasady otwartego i konkurencyjnego naboru, w miejsce którego wprowadzono zatrudnienie na podstawie powołania. Nadto zmieniły się warunki obsadzania Szefa Służby Cywilnej. Na podstawie nowych przepisów Szef Służby Cywilnej w momencie obejmowania stanowiska nie musi być urzędnikiem służby cywilnej, nie musi też posiadać doświadczenia na stanowiskach kierowniczych, jego zatrudnienie następuje na podstawie powołania, a odwołanie przez Prezesa Rady Ministrów może nastapić w każdej chwili bez wcześniejszej z konsultacji z jakimkolwiek ciałem doradczym.

$\mathrm{Na}$ podstawie przepisów ustawy z 30 grudnia 2015 r. o zmianie ustawy o służbie cywilnej zniesiono też Radę Służby Cywilnej, a w jej miejsce powołano Radę Służby Publicznej. Rada Służby Publicznej pozbawiona została w części dotychczasowych kompetencji opiniodawczych przysługujących wcześniej Radzie Służby Cywilnej. Nadto składa się ona wyłącznie z członków powoływanych i odwoływanych przez Prezesa Rady Ministrów.

II. W przepisie art. $153 \S 1$ Konstytucji ustalone zostały warunki działania korpusu służby cywilnej w urzędach administracji rządowej; ma on funkcjonować w celu zapewnienia zawodowego, rzetelnego, bezstronnego i politycznie neutralnego wykonywania zadań państwa. Takie same warunki działania służby cywilnej określa art. 1 ustawy o służbie cywilnej. Realizacja tych zasad $\mathrm{w}$ odniesieniu do zatrudnionych w służbie cywilnej odbywała się m.in. przez zapewnienie jasnych i obiektywnych kryteriów naboru do służby cywilnej oraz

1 Ustawa z 30 grudnia 2015 r. o zmianie ustawy o służbie cywilnej oraz niektórych innych ustaw, Dz. U. 2016, poz. 36 (dalej jako: ustawa o zmianie ustawy o służbie cywilnej).

${ }^{2}$ Ustawa z 21 listopada 2008 r. o służbie cywilnej, Dz. U. 2014, poz. 1111 ze zm. (dalej jako: ustawa o służbie cywilnej). 
awansu. Dotychczasowe przepisy ustawy o służbie cywilnej ustalały, że każdy obywatel ma prawo do informacji o wolnych stanowiskach pracy w służbie cywilnej, a nabór do służby cywilnej jest otwarty oraz konkurencyjny.

W literaturze ${ }^{3}$ wskazuje się, że otwartość naboru, o której stanowił art. 54 ust. 1 ustawy o służbie cywilnej przed nowelizacja, oznaczała jego powszechność, jawność i równość w ubieganiu się o zatrudnienie na wyższym stanowisku w służbie cywilnej. Natomiast konkurencyjność naboru oznaczała ${ }^{4}$ procedurę, w wyniku której na wyższym stanowisku w służbie cywilnej powinna zostać zatrudniona osoba, o wiedzy, umiejętnościach i innych cechach najbardziej odpowiednich spośród wszystkich zgłoszonych kandydatów do wykonywania pracy na stanowisku, na które poszukuje się pracownika.

Tymczasem zgodnie z treścią znowelizowanego art. 6 ustawy o służbie cywilnej każdy obywatel ma prawo do informacji o wolnych stanowiskach pracy w służbie cywilnej, a nabór do służby cywilnej jest otwarty oraz konkurencyjny, z zastrzeżeniem przepisów rozdziału 4, który dotyczy zatrudnienia na wyższych stanowiskach w służbie cywilnej. Oznacza to, że ustawodawca wyłączył prawo obywateli do informacji o wolnych wyższych stanowiskach w służbie cywilnej.

Po nowelizacji ustawy nabór do służby cywilnej osób zatrudnianych na wyższych stanowiskach nie będzie się już odbywał na zasadzie otwartości i konkurencyjności, ale na podstawie arbitralnego powołania, które pozostaje w sprzeczności z wynikającym z art. 60 Konstytucji RP prawem obywateli dostępu do służby publicznej na jednakowych zasadach. Należy zgodzić się z Rzecznikiem Praw Obywatelskich, który we wniosku ${ }^{5}$ o stwierdzenie niezgodności art. 1 pkt 14 ustawy o zmianie ustawy o służbie cywilnej z art. 153 ust. 1 Konstytucji wskazał, że likwidacja postępowania konkursowego oznacza likwidację proceduralnego miernika umożliwiającego kontrolę, czy dostęp ów odbywa się na równych zasadach. Likwidacja postępowania konkursowego oznacza też wyłączenie procedury umożliwiającej weryfikację, czy wyższe stanowiska w służbie cywilnej są obsadzane w sposób gwarantujący zawodowe, rzetelne, bezstronne i politycznie neutralne wykonywanie zadań państwa.

Należy też zauważyć, że ustawa nowelizująca ustawę o służbie cywilnej, likwidując w całości postępowanie konkursowe (uchylone art. 55-61 ustawy o służbie cywilnej), nie precyzuje sposobu, w jaki uzyskać będzie można wiedzę na temat wolnych wyższych stanowiskach w służbie cywilnej i jak będzie wyglądała procedura naboru na te stanowiska. Nasuwa się też pytanie, czy

\footnotetext{
${ }^{3}$ W. Perdeus, w: K. W. Baran (red.), Prawo urzędnicze - Komentarz, Warszawa 2014.

${ }^{4}$ W. Drobny, w: idem, M. Mazuryk, P. Zuzankiewicz, Ustawa o stużbie cywilnej. Komentarz, Warszawa 2012.

${ }^{5}$ Wniosek Rzecznika Praw Obywatelskich z 1 lutego 2016 r. o stwierdzenie niezgodności art. 1 pkt 14 ustawy z dnia 30 grudnia 2015 r. o zmianie ustawy o służbie cywilnej, art. 53a ustawy o służbie cywilnej dodanego przez art. 1 pkt 13 ustawy o zmianie ustawy o służbie cywilnej oraz art. 6 ust. 1 ustawy o zmianie ustawy o służbie cywilnej z Konstytucją RP, druk nr III.7040.9.2016. ST/LN.
} 
znowelizowany art. 6 ustawy o służbie cywilnej nie narusza ustawy o dostępie do informacji publicznej ${ }^{6}$.

Oceniając pod względem zgodności z Konstytucją odejście od zasady otwartości i konkurencyjności na rzecz zatrudnienia w służbie cywilnej na podstawie arbitralnego powołania, należy odnieść się do wyroku z 13 grudnia 2010 r. (III KRS 17/10), w którym Sąd Najwyższy stwierdził jednoznacznie, że art. 60 Konstytucji gwarantuje każdemu obywatelowi, korzystającemu z pełni praw publicznych, prawo dostępu do służby publicznej na jednakowych zasadach. W opinii Sądu Najwyższego z art. 60 Konstytucji wynika konstytucyjne prawo każdego do ubiegania się o przyjęcie do służby publicznej na jednakowych zasadach. Ustawodawca uprawniony jest do sformułowania szczegółowych warunków, uzależniając od ich spełnienia ubieganie się o określone stanowiska w służbie publicznej, z uwzględnieniem rodzaju stanowiska oraz jego charakteru. Organy władzy publicznej muszą ponadto określić liczbę obsadzanych stanowisk stosownie do potrzeb państwa. W tym kontekście celem art. 60 Konstytucji jest zapewnienie równości szans dla osób podejmujących starania o pełnienie funkcji w służbie publicznej; realizacja art. 60 Konstytucji z jednej strony wymaga od ustawodawcy ustanowienia regulacji materialnoprawnych, określających przejrzyste kryteria selekcji kandydatów i obsadzania poszczególnych stanowisk w służbie publicznej, a z drugiej strony nakazuje stworzenie odpowiednich gwarancji proceduralnych, zapewniających weryfikowalność decyzji w sprawie naboru do służby. Tymczasem nowe przepisy dotyczace zatrudnienia na wyższych stanowiskach w służbie cywilnej stoją w sprzeczności ze wskazanymi przez Są Najwyższy powinnościami wynikającymi z dyspozycji art. 60 Konstytucji.

III. W uzasadnieniu ${ }^{7}$ projektu ustawy o zmianie ustawy o służby cywilnej jako przyczynę wprowadzenia zatrudnienia na podstawie powołania podano, że dotychczasowa praktyka stosowania ustawy o służbie cywilnej wskazywała na niejednokrotnie wydłużające się i nieefektywne procedury rekrutacji w drodze otwartego i konkurencyjnego naboru, które to procedury prowadziły do opóźnień w obsadzeniu wolnych stanowisk. W uzasadnieniu wskazano także, że zjawisko to jest szczególnie niepożądane w przypadku wyższych stanowisk w służbie cywilnej, które to stanowiska są związane z wykonywaniem polityki rządu oraz zapewnieniem sprawnego administrowania i zarządzania kadrami.

Godzi się jednak zauważyć, że autorzy uzasadnienia projektu ustawy nie przedstawili żadnych danych statystycznych, informacji źródłowych bądź wyliczeń finansowych odnośnie do „opóźnień w obsadzaniu wolnych stanowisk”. Tym bardziej zabrakło takich danych w zakresie obsadzania wyższych stanowisk w służbie cywilnej, gdzie zjawisko to miało być „szczególnie niepożądane”.

${ }^{6} \mathrm{Na}$ podstawie art. 1 ust. 1 ustawy z 6 września 2001 r. o dostępie do informacji publicznej (Dz. U. 2001, Nr 112, poz. 1198 ze zm.) każda informacja o sprawach publicznych stanowi informację publiczną w rozumieniu ustawy i podlega udostępnieniu i ponownemu wykorzystywaniu na zasadach i w trybie określonych w niniejszej ustawie.

7 Druk sejmowy nr 119/2015. 
Natomiast w uzasadnieniu projektu zmiany ustawy o służbie cywilnej wskazano dodatkowo, że biorąc pod uwagę znaczenie i zakres zadań wykonywanych na wyższych stanowiskach w służbie cywilnej oraz potrzebę zapewnienia sprawnego funkcjonowania służby cywilnej realizującej działania rządu, zasadne jest, aby zatrudnianie na wyższych stanowiskach w służbie cywilnej ${ }^{8}$ odbywało się w sposób elastyczny i mniej sformalizowany, tj. na podstawie powołania.

Zwraca uwagę okoliczność, że uzasadnienie projektu ustawy o zmianie ustawy o służbie cywilnej jest bardzo podobne do uzasadnienia ustawy o służbie cywilnej z 24 sierpnia 2006 r. ${ }^{9} \mathrm{~W}$ uzasadnieniu projektu tej ustawy ${ }^{10}$ odejście od konkurencyjnego naboru na podstawie konkursu w stosunku do części dotychczasowych członków korpusu służby cywilnej motywowano koniecznością dostosowania stosunku pracy tych osób do realizacji polityki rządu, która wymaga podejmowania szybkich decyzji kadrowych w krótkim czasie oraz w sposób elastyczny, uwzględniajaccy wysokie kwalifikacje kandydatów, którzy mogą reprezentować inne niż administracja państwowa dziedziny życia gospodarczego i społecznego.

Dodatkowo w opinii autorów projektu ustawy o służbie cywilnej z 2006 r. dotychczasowe umocowanie kadry kierowniczej w ramach stosunku pracy na podstawie mianowania i przeniesienia po wygranym konkursie było sprzeczne z zasadami efektywnego i racjonalnego zarządzania wzorowanego na sektorze prywatnym. W uzasadnieniu ustawy o służbie cywilnej z 2006 r. wskazano wprost, że kadra kierownicza wyższego szczebla powinna realizować politykę rządu, ministra, kierownika urzędu centralnego i wojewody, organizować pracę członków korpusu służby cywilnej i w związku z tym wymagane jest, aby mogła być elastycznie dostosowana do aktualnych potrzeb w tym zakresie, zarówno pod względem kierunku i typu wykształcenia, posiadanych umiejętności, jak i predyspozycji osobowościowych. Przy czym i w uzasadnieniu projektu ustawy o służbie cywilnej z 2006 r. nie podano wyników żadnych badań bądź danych statystycznych wykazujacych, że dotychczasowe zasady zatrudnienia były „sprzeczne z zasadami efektywnego i racjonalnego zarządzania wzorowanego na sektorze prywatnym".

Należy zauważyć, że ustawa o służbie cywilnej z 2006 r. utrzymała się tylko przez dwa lata i w 2008 r. została uchylona, podobnie jak ustawa

\footnotetext{
${ }^{8}$ Zatrudnianie na wyższych stanowiskach w służbie cywilnej dotyczy następujących stanowisk: dyrektora generalnego urzędu, kierującego departamentem lub komórką równorzędna w Kancelarii Prezesa Rady Ministrów, urzędzie ministra, urzędzie obsługującym przewodniczącego komitetu wchodzącego w skład Rady Ministrów, urzędzie centralnego organu administracji rządowej oraz kierującego wydziałem lub komórką równorzędną w urzędzie wojewódzkim, a także zastępcy tych osób, wojewódzkiego lekarza weterynarii i jego zastępcy, kierującego komórką organizacyjną w Biurze Nasiennictwa Leśnego, a także zastępcy tej osoby, wojewódzkiego lekarza weterynarii i jego zastępcy; kierującego komórką organizacyjną w Biurze Nasiennictwa Leśnego, a także zastępcy tej osoby. Od 1 lipca 2016 r. do wyższych stanowisk w służbie cywilnej zostana zaliczone stanowiska: dyrektora izby skarbowej i jego zastępcy, dyrektora Biura Krajowej Informacji Podatkowej i jego zastępcy, naczelnika urzędu skarbowego.

${ }^{9}$ Ustawa z 24 sierpnia 2006 r. o służbie cywilnej, Dz. U. Nr 170, poz. 1218 (dalej jako: ustawa o służbie cywilnej z 2006 r.).

${ }^{10}$ Uzasadnienie projektu ustawy o służbie cywilnej z 24 sierpnia 2006 r. - druk sejmowy nr 552/2006, s. 2.
} 
o państwowym zasobie kadrowym i wysokich stanowiskach państwowych ${ }^{11}$, przez z ustawę o służbie cywilnej z 28 listopada 2008 r., która przywróciła konkurencyjne i otwarte zatrudnienie na wyższych stanowiskach w służbie cywilnej

Jako podstawę wprowadzenia powołania w uzasadnieniu projektu ustawy o zmianie ustawy o służbie cywilnej z 2015 r. podano konieczność sprawnego zatrudnienia na wyższych stanowiskach w służbie cywilnej osób spełniających wymagania przewidziane dla tych stanowisk w ustawie o służbie cywilnej, a przy tym posiadających wykształcenie, umiejętności i predyspozycje dostosowane do aktualnych potrzeb urzędu.

Niewątpliwie zastosowanie powołania usprawni i przyspieszy proces nawiąywania stosunku pracy na wyższych stanowiskach w służbie cywilnej. Jednak w piśmiennictwie dotyczacym powołania ${ }^{12}$ wskazuje się, że stosunek pracy na tej podstawie charakteryzuje się większą zależnością pracownika od pracodawcy, niż w przypadku zatrudnienia na podstawie umowy o pracę czy mianowania. Na podstawie obowiązujących przepisów Kodeksu pracy pracodawca może bowiem w każdej chwili odwołać zatrudnionego pracownika bez podania przyczyny, a pracownikowi $\mathrm{w}$ takim przypadku przysługuje jedynie możliwość dochodzenia odszkodowania, nie może domagać się przywrócenia do pracy. Taki model zatrudnienia przeniesiony na grunt służby cywilnej wpływa na zwiększoną dyspozycyjność powołanych pracowników wobec swych przełożonych i stanowi zaprzeczenie zasady bezstronności i politycznej neutralności. Jak wskazuje Hubert Izdebski ${ }^{13}$ w opinii dotyczącej ustawy o zmianie ustawy o służbie cywilnej, wprowadzenie powołania jako podstawy zatrudnienia przy równoczesnym wprowadzeniu dodatkowego uproszczenia zatrudnienia umożliwi wprost polityzację kierowniczego segmentu służby cywilnej.

Wprowadzenie powołania jako podstawy zatrudnienia na wyższych stanowiskach w służbie cywilnej powiązane zostało dodatkowo ze zniesieniem większości wymogów dotyczących przyjęcia do pracy na wyższych stanowiskach w służbie cywilnej. Kandydaci na wyższe stanowiska w służbie cywilnej nie muszą już spełniać warunku co najmniej sześcioletniego stażu pracy, w tym co najmniej trzyletniego stażu pracy na stanowisku kierowniczym $\mathrm{w}$ jednostkach sektora finansów publicznych (w przypadku ubiegania się o stanowisko dyrektora generalnego urzędu) oraz co najmniej trzyletniego stażu pracy, w tym co najmniej rocznego na stanowisku kierowniczym lub dwuletniego na stanowisku samodzielnym, w jednostkach sektora finansów publicznych (w przypadku ubiegania się o pozostałe wyższe stanowiska). Od kandydata na wyższe stanowiska w służbie cywilnej wymaga się tylko spełnienia cenzusu wyższego wykształcenia, posiadania kompetencji kierowniczych oraz niekaralności.

Zgodnie ze zmienioną ustawą o służbie cywilnej osoby, które zajmują wyższe stanowiska w służbie cywilnej, będą nadal członkami korpusu służby

11 Ustawa z 24 sierpnia 2006 r. o państwowym zasobie kadrowym i wysokich stanowiskach państwowych, Dz. U. Nr 170, poz. 1217 (dalej jako: ustawa o państwowym zasobie kadrowym).

${ }_{12}$ D. Doerre-Nowak, w: B. Wagner (red.), Kodeks pracy-Komentarz, Gdańsk 2010, s. 404 i n.

${ }^{13}$ Opinia prawna prof. Huberta Izdebskiego z 3 lutego 2016 w przedmiocie ustawy z dnia 30 grudnia 2015 r. o zmianie Ustawy o służbie cywilnej oraz niektórych innych ustaw. 
cywilnej. Oznacza to, że przepisy ustawy o służbie cywilnej adresowane do członków korpusu służby cywilnej powinny mieć zastosowanie także do osób zajmujacych wyższe stanowiska w służbie cywilnej. Nowelizacja wprowadziła jednak różnice między osobami zajmującymi wyższe stanowiska w służbie cywilnej i pozostałymi członkami korpusu służby cywilnej.

W szczególności na podstawie znowelizowanego art. 81 ustawy o służbie cywilnej wyższe stanowiska w służbie cywilnej nie będą objęte systemem ocen okresowych. Nadto zajmujące je osoby będą mogły uczestniczyć w szkoleniach, ale nie będzie dla nich ustalany indywidualny program rozwoju zawodowego. Natomiast osoby zajmujace wyższe stanowiska w służbie cywilnej będą tak jak pozostali członkowie korpusu służby cywilnej podlegały odpowiedzialności dyscyplinarnej.

Wprowadzenie powoływania pracowników na wyższych stanowiskach w służbie cywilnej miało już raz miejsce - wprowadzono ustawę z 24 sierpnia 2006 r. o służbie cywilnej, a równolegle z nią ustawę z 24 sierpnia $2006 \mathrm{r}$. o państwowym zasobie kadrowym. Wtedy jednak osoby zajmujące wyższe stanowiska w służbie cywilnej miały funkcjonować poza korpusem służby cywilnej, na odrębnej podstawie prawnej, jaką była ustawa o państwowym zasobie kadrowym. Jak już wyżej wspomniano, obie ustawy z 2006 r. utrzymały się tylko dwa lata i zostały zastapione przez ustawę o służbie cywilnej z 2008 r., która powróciła do modelu kariery.

Dodatkowym naruszeniem stabilizacji zatrudnienia na wyższych stanowiskach w służbie cywilnej jest wprowadzenie przepisu art. 6 ust. 1 ustawy zmieniającej ustawę o służbie cywilnej, na podstawie którego stosunki pracy $\mathrm{z}$ osobami zajmującymi w dniu wejścia $\mathrm{w}$ życie tej ustawy wyższe stanowiska w służbie cywilnej wygasaja po upływie 30 dni od dnia wejścia w życie ustawy, jeżeli przed upływem tego terminu nie zostaną im zaproponowane nowe warunki pracy lub płacy na dalszy okres albo w razie nieprzyjęcia nowych warunków pracy lub płacy. Nadto ewentualne wcześniejsze rozwiązanie stosunku pracy może nastapić za wypowiedzeniem.

Odnosząc się do treści przepisu art. 6 ust. 1 ustawy zmieniającej ustawę o służbie cywilnej, przede wszystkim należy zauważyć, że nawet zarzuty dotyczące opóźnień w obsadzaniu wolnych stanowisk w służbie cywilnej nie moga uzasadniać działań ustawodawcy polegających na opróżnieniu już obsadzonych w wyniku konkursu stanowisk. Tymczasem wprowadzenie przepisu wygaszającego stanowiska w służbie cywilnej oznacza, że de facto na podstawie zmienionej ustawy o służbie cywilnej weryfikacji podlegać będą wszyscy zatrudnieni dotychczas w służbie cywilnej na wyższych stanowiskach w wyniku otwartego i konkurencyjnego naboru. Przepisu art. 6 ust. 1 ustawy zmieniającej ustawę o służbie cywilnej ustala bowiem jedynie możliwość zaproponowania tym pracownikom nowych warunków pracy, co leżeć będzie w niczym nieograniczonej dyspozycji kierowników poszczególnych urzędów.

Osobom zajmującym wyższe stanowiska w służbie cywilnej, których stosunki pracy wygasną w związku z nieprzedstawieniem im nowych warunków pracy lub płacy albo $\mathrm{w}$ razie nieprzyjęcia przez nie nowych warunków pracy 
lub płacy, przysługiwać będzie odprawa pieniężna przewidziana dla pracowników, z którymi stosunki pracy rozwiązuje się z powodu likwidacji urzędu. Jednak będzie to niewielka rekompensata dla pracowników, którzy ze służba cywilną wiązali swoja karierę zawodowa. Dotychczasowy model promował, przez możliwość awansu stanowiskowego, jak i finansowego, właśnie długoletnie, stabilne budowanie kariery w służbie cywilnej.

W kwestii naruszenia przez art. 6 ustawy zmieniającej ustawę o służbie cywilnej stałości zatrudnienia i awansu w służbie cywilnej należy odwołać się do wyroku Trybunał Konstytucyjny z 12 grudnia 2002 r. ${ }^{14}$, w którym wskazano wprost, że zawodowe wykonywanie zadań państwa oznacza konieczność zatrudniania osób, które traktują wykonywanie tych zadań jako zawód. Oznacza to, że zatrudnienie w ramach służby cywilnej nie ma być jedynie przejściowym zajęciem, ale stałym źródłem utrzymania oraz miejscem pracy, zapewniającym osobom kompetentnym możliwość realizacji kariery zawodowej.

IV. Zmiany w służbie cywilnej obejmują też istotną weryfikację stanowiska Szefa Służby Cywilnej, który dotychczas powoływany był przez Prezesa Rady Ministrów, po zasięgnięciu opinii Rady Służby Cywilnej. Po nowelizacji Szefa Służby Cywilnej powołuje i odwołuje Prezes Rady Ministrów. Przy czym usunięto dotychczasowe warunki odwołania Szefa Służby Cywilnej określone w art. 12 ustawy o służbie cywilnej ${ }^{15}$, który enumeratywnie wskazywał takie przypadki. Po nowelizacji premier będzie mógł arbitralnie w każdej chwili go odwołać.

W znowelizowanej ustawie o służbie cywilnej znosi się także zasadę, że Szef Służby Cywilnej musi posiadać co najmniej pięcioletnie doświadczenie na stanowisku kierowniczym w administracji rządowej lub co najmniej siedmioletnie doświadczenie na stanowisku kierowniczym w jednostkach sektora finansów publicznych. Dodatkowo na podstawie uchylonych przepisów, ubiegając się o to stanowisko kandydat musiał potwierdzić, że nie jest i w okresie ostatnich 5 lat nie był członkiem partii politycznej. Po zmianie przepisów Szef Służby Cywilnej, dopiero w momencie obejmowania stanowiska nie może być członkiem partii politycznej. Wobec tego nie ma żadnych przeszkód, aby stanowisko to objęła osoba, która bezpośrednio przed powołaniem należała do partii politycznej.

Nadto dotychczas Szef Służby Cywilnej, w porozumieniu z Prezesem Rady Ministrów, wyznaczał zastępująca go osobę spośród urzędników służby cywilnej. Po nowelizacji osobą zastępującą Szefa Służby Cywilnej nie musi już być urzędnikiem służby cywilnej, ale może tę funkcję piastować jakakolwiek oso-

\footnotetext{
${ }^{14}$ K 9/02, OTK-A 2002, z. 7, poz. 94 (dalej jako: wyrok TK z 12 grudnia 2002 r.).

${ }^{15} \mathrm{Na}$ podstawie art. 12 ustawy o służbie cywilnej Prezes Rady Ministrów odwoływał Szefa Służby Cywilnej z zajmowanego stanowiska w przypadku: 1) złożenia rezygnacji; 2) jeżeli Szef Służby Cywilnej przestawał spełniać którykolwiek z warunków określonych w art. 11 ust. 1 pkt 1-4, 7 lub 9 ustawy o służbie cywilnej; 3) nie wypełniał obowiązków na skutek długotrwałej choroby, stwierdzonej orzeczeniem lekarskim.
} 
ba, której kompetencje, doświadczenie czy status nie zostały w znowelizowanej ustawie w żadnym zakresie określone.

Analiza zmian przepisów dotyczących warunków zatrudnienia Szefa Służby Cywilnej wywołuje wątpliwość, czy osoba pełniąca tę funkcję będzie w stanie realizować powierzone jej zadania bezstronnie i w sposób politycznie neutralny. Nadto pozbawienie wszelkich wymagań kompetencyjnych w stosunku do jego zastępcy, który nie musi być też urzędnikiem służby cywilnej, każe zadać pytanie, czy taka osoba spełni warunek rzetelnego i zawodowego wykonywania powierzonych zadań.

V. W ramach zmiany ustawy o służbie cywilnej likwidacji uległa Rada Służby Cywilnej, a na jej miejsce wprowadzono Radę Służby Publicznej działająca przy Prezesie Rady Ministrów. Rada utrzymała dotychczasową rolę organu opiniodawczo-doradczego. Jednak z zakresu jej kompetencji wyłaczono doradzanie Prezesowi Rady Ministrów przy powoływaniu i odwoływaniu Szefa Służby Cywilnej. Do kompetencji Rady Służby Publicznej (których wcześniej nie posiadała Rada Służby Cywilnej) zaliczono natomiast określanie kierunków modernizacji służby cywilnej pod kątem zmieniających się zadań, potrzeb i oczekiwań Prezesa Rady Ministrów. Nadto Rada we współpracy z Krajową Szkoła Administracji Publicznej ma upowszechniać najlepsze europejskie standardy, wzorce i doświadczenia w zakresie funkcjonowania służby publicznej.

Rada Służby Publicznej będzie składała się z 7-9 członków, przy czym to Prezes Rady Ministrów samodzielnie powołuje wszystkich członków Rady spośród osób, których wiedza, doświadczenie i autorytet daja rękojmię prawidłowej realizacji jej zadań. Premier ma więc całkowity wpływ na skład Rady Służby Publicznej. Tymczasem dotychczas Rada Służby Cywilnej składała się z 15 członków, a Prezes Rady Ministrów powoływał 8 członków spośród osób, których wiedza, doświadczenie i autorytet dawały rękojmię prawidłowej realizacji jej zadań. Natomiast pozostałych 7 członków Prezes Rady Ministrów powoływał, na wniosek klubów parlamentarnych, spośród posłów, senatorów lub osób niebędących parlamentarzystami, których wiedza, doświadczenie i autorytet dawały rękojmię prawidłowej realizacji zadań Rady.

VI. W wyroku z 20 kwietnia 2004 r. ${ }^{16}$ Trybunał Konstytucyjny wskazał, że status osoby pozostającej w stosunku służbowym powinien sprowadzać się do bezstronnego, apolitycznego, fachowego wykonawcy zadań państwa. Trybunał Konstytucyjny podkreślił w odniesieniu do służby cywilnej, że podstawowym i koniecznym elementem pozwalającym zachować neutralność polityczna korpusu jest takie ustawowe ukształtowanie powoływania i funkcjonowania służby cywilnej, które zagwarantuje brak, choćby przejściowych, możliwości jakiejkolwiek ingerencji w tym zakresie ze strony polityków sprawujących władzę. Tymczasem omawiane $\mathrm{w}$ niniejszym artykule zmiany w ustawie o służbie cywilnej prowadzą w odmiennym kierunku - podporządkowania służby

${ }^{16} \mathrm{~K} 45 / 02(30 / 4 \mathrm{~A} / 2004)$. 
cywilnej wpływom politycznym. Poza tym idą też one w stronę zmniejszenia gwarancji stabilności zatrudnienia, obniżenia kwalifikacji koniecznych do rozpoczęcia pracy w służbie cywilnej oraz ograniczenia obiektywnych kryteriów nawiązania stosunku pracy. Te negatywne zmiany mogą w krótkim czasie doprowadzić do istotnego obniżenia standardów wykonywania zadań powierzonych służbie cywilnej. W dalszej perspektywie powodować to może obniżenie autorytetu i znaczenia administracji jako jednego z podmiotów realizujacych podstawowe funkcje państwa wobec obywateli.

dr Sebastian Samol

Uniwersytet im. Adama Mickiewicza w Poznaniu

sseb@wp.pl

\section{A CHANGE IN THE MODEL OF CIVIL SERVICE AFTER THE AMENDMENTS}

TO THE ACT ON CIVIL SERVICE

\section{Summary}

Changes in the employment in civil service arising from the implementation of the Act Amending Civil Service and some other acts of 30 December 2015 are discussed. The results of an analysis of new conditions of employment for civil service positions based upon appointment are presented together with the conditions necessary for performing the function by the Chief of Civil Service as well as the principles upon which the Council of the Public Service that replaced the Council of Civil Service. 
